\title{
Design and Fabrication of Coir Pith briquetting Machine
}

\author{
PADMARAJ ANNAJI, Assistant Professor, SDMIT, Ujire, India. padmarajannaji@gmail.com
}

\begin{abstract}
Small scale industries play a major role in the economic development of India, to enhance its growth and to effectively utilize the renewable energy, waste products to be reused one such product is coir pith. Coir Pith is the spongy, peat like residue from the processing of coconut husk and it is pressed to required thickness in order to make it as pith briquettes. Coir is mainly used in exporting and in agricultural field, as it is good absorbent of the water. It maintains the moisture content of the pith to enhance the quality of the product. The purpose of this project work is to design and fabricate "COIR PITH PREOUETTING MACHINE" for maintaining the growth of the plants in the potting medium with less consumption of electricity and labors.
\end{abstract}

Keywords -Coir, Manure, Capillarity, Briquetting, Absorption capacity

\section{INTRODUCTION}

As improved technology increases production, industry groups and governmental agencies are actively promoting new uses for coir fiber. Geotextiles is one promising area. The Indian state of Kerala designated 2000 as Coir Geotextiles Year, which it observed by increasing marketing efforts and supporting research to improve production. The annual world demand for geotextiles is 1.2 billion square yards (1 billion square meters) and growing. Although natural fibers account for only $5 \%$ of that, the proportion is expected to increase as more users turn away from no biodegradable synthetics.

Another new product under development is an alternative to plywood that is made by impregnating a coir mat with phenol formaldehyde resin and curing it under heat and pressure.

Soil quality has a key role in the making of Home gardens, Terrace gardens, Lawns, Nurseries as well as in Horticulture and Floriculture. Factors like salinity and less water holding capacity make soil unsuitable for cultivation. Coir pith is an ideal soil re-conditioner, soil structure improver and soil substrate with excellent water holding capacity.

The purpose of this project work is to design and fabricate coir pith briquetting machine for maintaining the growth of the plants in the potting Medium with less consumption of electricity and labours.

\section{COIR FIBER AND Properties}

\section{A. Coir [7]}

What is commonly called a coconut, as found in grocery stores, is actually only the single leed of a fruit of the coconut palm tree (Cocos nucifera). Before being shipped to market, the seed is stripped of an external leathery skin and a $2-3$ in $(5-8 \mathrm{~cm})$ thick intermediate layer of fibrous pulp. Fibers recovered from that pulp are called coir. The Fibers range from sturdy strands suitable for brush bristles to filaments that can be spun into coarse, durable yam. In the United States, the most popular uses for coir are bristly door mats, agricultural twine, and geotextiles (blankets that are laid on bare soil to control erosion and promote the growth of protective ground covers).

[8]Coir fibers are categorized in two ways. One distinction is based on whether they are recovered from ripe or immature coconut husks. The husks of fully ripened coconuts yield brown coir. Strong and highly resistant to abrasion, its method of processing also protects it from the damaging ultraviolet component of sunlight. Dark brown in color, it is used primarily in brushes, floor mats, and upholstery padding. On the other hand, white coir comes from the husks of coconuts harvested shortly before they ripen. Actually light brown or white in color, this fiber is softer and less strong than brown coir. It is usually spun into yarn, which may be woven into mats or twisted into twine or rope. The other method of categorization is based on fiber length. Both brown and white coir consist of fibers ranging in length from 4-12 in $(10-30 \mathrm{~cm})$. Those that are at least 8 in $(20 \mathrm{~cm})$ long are called bristle fiber. Shorter fibers, which are also finer in texture, are called mattress fiber. A $10-\mathrm{oz}$ (300-g) coconut husk yields about $3 \mathrm{oz}$ (80 g) of fiber, onethird of which is bristle fiber.

\section{B. Coir Properties}

The only natural fiber resistant to salt water, coir is used to make nets for shellfish harvesting and ropes lor marine applications. Highly resistant to abrasion, coir fibers are used to make durable floor mats and brushes. Strong and nearly impervious to the weather, coir twine is ihe material hops growers in the United States prefer for tying their vines to supports. Coir is becoming a popular choice for making geotextiles because of its durability, eventual biodegradability, ability to hold water, and hairy texture (which helps it cling to seeds and soil). 
Table1: Properties of coir with other natural fibres

\begin{tabular}{|l|c|c|c|}
\hline \multicolumn{1}{|c|}{ Properties } & $\begin{array}{c}\text { Coir } \\
\text { pith }\end{array}$ & Jute & $\begin{array}{c}\text { Cotto } \\
\mathrm{n}\end{array}$ \\
\hline Density $\left(\mathrm{cm}^{3}\right)$ & 125 & 146 & 151 \\
\hline Tensile strength (Mpa) & 220 & $\begin{array}{c}400- \\
800\end{array}$ & 400 \\
\hline Elastic Modulus Gpa & 6 & $10-30$ & 12 \\
\hline specific density & 5 & $7-21$ & 8 \\
\hline $\begin{array}{l}\text { Relative price compared to } \\
\text { Coir }\end{array}$ & $15-25$ & 18 & $3-10$ \\
\hline Elongation at failure \% & $15-25$ & 18 & $3-10$ \\
\hline
\end{tabular}

Table 2: Chemical Properties [6]

\begin{tabular}{|l|c|c|c|c|c|c|c|}
\hline Material & $\begin{array}{l}\text { Moisture } \\
(\%)\end{array}$ & $\mathrm{pH}$ & $\begin{array}{c}\mathrm{EC} \\
(\mathrm{dS} / \mathrm{m})\end{array}$ & $\mathrm{N}$ & $\mathrm{P}$ & $\mathrm{K}$ & $\mathrm{Cl}$ \\
\hline Coir peat & 13 & 5.1 & .80 & $\begin{array}{c}0 . \\
5\end{array}$ & $\begin{array}{c}0 . \\
3\end{array}$ & $\begin{array}{c}0 . \\
4\end{array}$ & $\begin{array}{c}0.0 \\
7\end{array}$ \\
\hline $\begin{array}{l}\text { Sphagnum } \\
\text { peat }\end{array}$ & 9 & 3.3 & 0.85 & $\begin{array}{c}0 . \\
9\end{array}$ & $\begin{array}{c}0 . \\
5\end{array}$ & $\begin{array}{c}0.0 .0 \\
1\end{array}$ \\
\hline Sedge peat & 83 & 4.9 & 0.35 & $\begin{array}{c}0 . \\
9\end{array}$ & $\begin{array}{c}0 . \\
5\end{array}$ & $\begin{array}{c}0.0 \\
1\end{array}$ \\
\hline
\end{tabular}

Table 3: Physical Data [7]

\begin{tabular}{|c|c|c|c|c|}
\hline Material & $\begin{array}{c}\text { Dry } \\
\text { weight }\end{array}$ & $\%$ WHC (A) & (B) & $\%$ AFP \\
\hline Coir dust & 9 & 52 & 69 & 15 \\
\hline
\end{tabular}

From Table-1 it is shown that coir has high lignin content which prompt to fighting against bacterial and fungul activities. So that it can be effectively utilized in the agricultural field and potting agent. Coir Pith briquetting is done with the help of pneumatic piston rod. Pneumatic source effectively utilized in the briquetting technology, different type of pressing arc Piston and Ram and Screw briquetting.[2]

At present two main high pressure technologies: Ram or piston press and screw extrusion machines are used for briquetting. The briquettes produced by a piston press are completely solid. screw press briquettes on the other hand have a concentric hole which gives better combustion characteristics due to a larger specific area. The screw press briquettes are also homogeneous and do not disintegrate easily. The pollution problem is become so acute, that the State Government of Tamil Nadu has banned the burning of loose Coir in southern areas. It is very likely that other States in India will soon follow this policy. The users are advised to use coir either as briquetted material or in fluidized bed boilers with proper pollution control measures.[4] On the basis of compaction, the briquetting technologies can be divided into:

--High Pressure compaction

--Medium Pressure compaction with a heating device

--Low pressure compaction with a binder

In all these compaction techniques, solid particles are the starting materials. The individual particles are still identifiable to some extent in the final product. Briquetting and extrusion both represent compaction.

\section{WORKING METHODOLOGY}

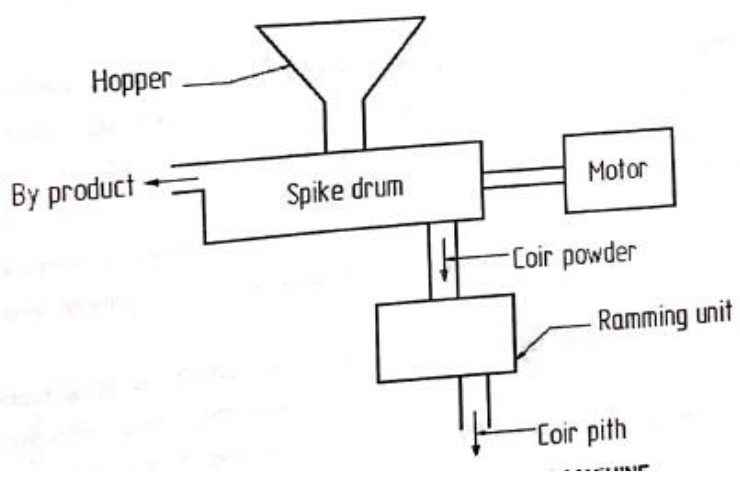

Fig 1: Block diagram of coir pith briquetting machine

Drying of fibre: Initially the fibre of the coco and jute are dried of the coconut fibre from husks, gives the by-product called coco pen. This coco pea is dried in the sun, are processed to produce different items. This makes an excellent growing medium for hydroponics or container plant growing. Clean coir has natural rooting hormones and anti-fungal properties. Most of all coco peat is $100 \%$ organic natural and root friendly product. An organic potting medium made from natural fibres, this all natural material is not only ideal for hydroponics and mixed media cultivation, but is an excellent soil conditioner as well. This material loosens clay soils and is highly porous to aid in strong root development. It has a soft fibrous texture that does not crust when dry.

Separation of pith: After drying the fibres are separated according to the quality, so that low quality fibres are used for the purpose of making the preserver sponge. High quality fibres are used for toys making and commercial products. Coir dust is the spongy, peat like residue from the processing of coconut husks (meso carp) for coir fibre. Also known as coco peat, it consists of short fibres $(<2 \mathrm{~cm})$ around $2 \%-13 \%$ of the total and cork like particles ranging in size from granules to fine dust.

Powdering of the fibre: Separated fiber is taken and dropped into the revolving drum studded with metal spikes that comb the fibers out. Automatic process starts by grinding the fiber to required consistency, filtering and pressing. Grinding mechanism consist of nested bowl with spikes attached to single phase induction motor so that motor rotates the bowl and the powdered pith fall into the filter.

Filtration: filtering of the sand dust and waste material is done in the filtration process and the powder is transferred to the hopper.

Compaction: The pith in the hub is pressed using the cylinder rod in which presses are given on the coir powder for making the pith. 
One of the most important attributes of coir dust is its ease of wetting. Unlike peat Incoming increasingly difficult to rewet as it dries down (said to be hydrophobic), coir dust mains relatively hydrophilic (water attracting) even when it is air dry. The coir pith is functional where overhead irrigation is used (sprinklers,misters and drippers), the presence of coir dust in a mix ensues quick and efficient rewetting.

\section{DESIGN OF PARTS}

\section{Design of Hopper}

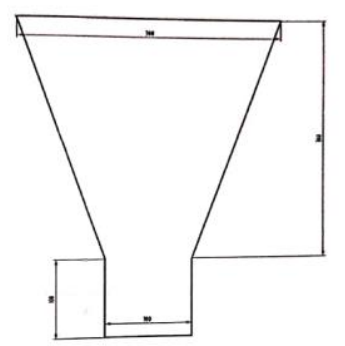

Fig 2: Hopper

Hopper is used for collecting the coconut husks.

Volume of the Hopper ( $\mathrm{Vh})$ :

$$
\begin{aligned}
& \mathrm{Vh}=(1 / 3) * \mathrm{jt} *(\mathrm{R} 2-\mathrm{r} 2) * \mathrm{~h} \\
& \mathrm{Vh}=(1 / 3) * 7 \mathrm{t} *(1502-502) * 400
\end{aligned}
$$$$
\mathrm{Vh}=8.37 * 10^{6} \mathrm{~mm}^{3} \text {. }
$$

Mass of coir (M1):

$$
\begin{aligned}
& \mathrm{M} 1=\rho * \mathrm{Vh} \\
& \mathrm{M} 1=\left(0.341 * 8.37 * 10^{6)} / 1000\right. \\
& \mathrm{M} 1=2.85417 \mathrm{~kg}
\end{aligned}
$$

\section{Design of Spike Drum}

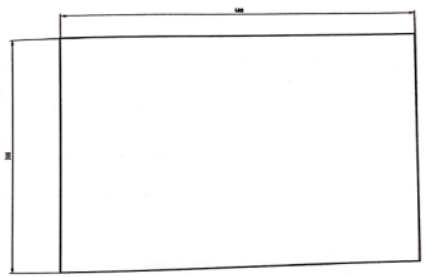

Fig 3: Spike drum

Spike drum is a hollow shaft used for filtering or separating the coir and coir powder.

Volume of the drum $(\mathrm{Vd})$ :

$$
\begin{aligned}
& \mathrm{Vd}=\pi * \mathrm{rc}^{2} * \mathrm{~h}=\pi^{*} 150^{2} * 400 \\
& \mathrm{Vd}=28.27 * 10^{6} \mathrm{~mm}^{3}
\end{aligned}
$$

Mass of coir (M2)

$$
\mathrm{M} 2=\rho * \mathrm{Vd}=\left(0341 * 28.27 * 10^{6}\right)=9.64007 \mathrm{~kg}
$$

\section{Rotating drum:}

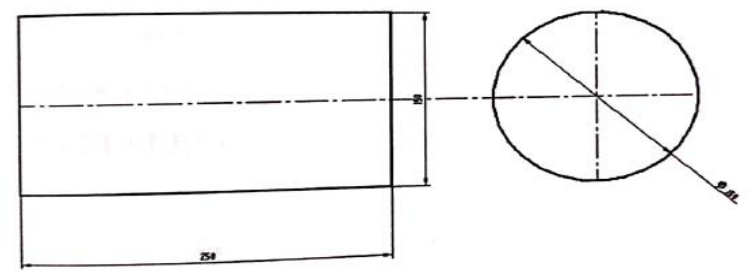

Fig 4: Rotating drum

Rotating drum is connected to the motor shaft through flange coupling, used to crush the husk due to abrasion.

Length $=250 \mathrm{~mm}$

Diameter $=150 \mathrm{~mm}$

Material $=$ mild steel

4. Driver Pulley:

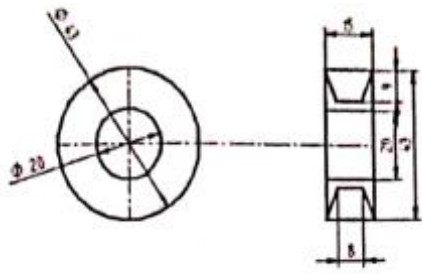

Fig 5: Driver pulley

Inner diameter $\left(\mathrm{d}_{\mathrm{i}}\right)=20 \mathrm{~mm}$

Outer diameter $\left(\mathrm{d}_{0}\right)=43 \mathrm{~mm}$

\section{Driven Pulley:}

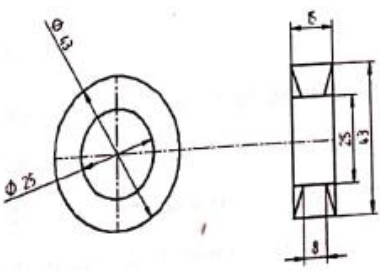

Fig 6: Driven pulley Driven pulley is mounted on driven shaft and carries belt required to transfer the power between shafts. Inner diameter of the pulley (di) $=25 \mathrm{~mm}$ Outer diameter of the pulley (do) $=43 \mathrm{~mm}$ 6. Shaft:

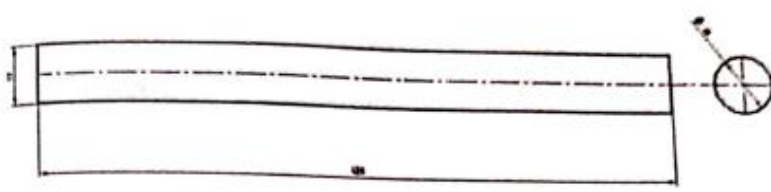

Fig 7: Shaft

Material used Mild Steel

Length of the shaft $(\mathrm{Ls})=480 \mathrm{~mm}$

Diameter of the shaft $(\mathrm{ds})=45 \mathrm{~mm}$

Shaft is a straight bar usually of circular cross section. It is used to transmit power from motor to compressor, turbine or generator, motor to pump and so on. Two equal and opposite couples acting about the axis of the shaft results in torsion.

\section{Screw Press:}

7.1 Cylinder

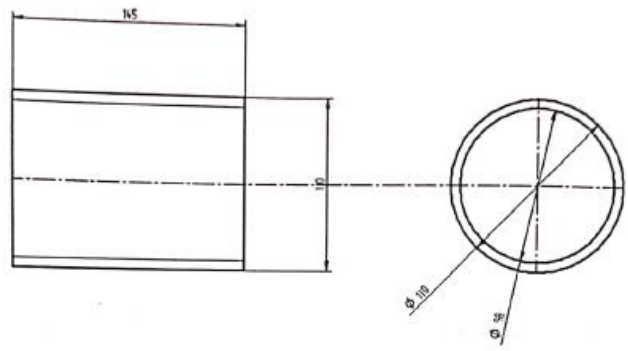

Fig 8: Cylinder

Hollow cylinder is placed to surround the rotating drum 
and keeps the husk in place.

Length of the cylinder $\left(\mathrm{L}_{\mathrm{c}}\right)=145 \mathrm{~mm}$

Outer diameter of the cylinder $\left(\mathrm{d}_{\mathrm{co}}\right)=110 \mathrm{~mm}$

Inner diameter of the cylinder $\left(\mathrm{d}_{\mathrm{ci}}\right)=98 \mathrm{~mm}$

Thickness of the cylinder $\left(\mathrm{t}_{\mathrm{c}}\right)=6 \mathrm{~mm}$

7.2 Screw:

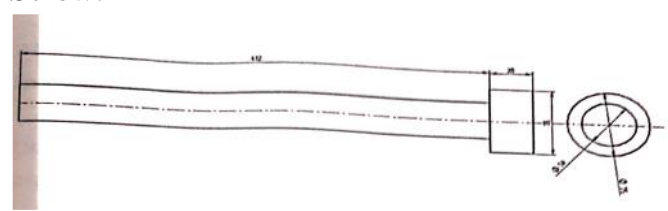

Fig 9: Screw

Screw is used to apply the pressure on coir powder so as to form the billet.

Length of the screw $(\mathrm{Ls})=412 \mathrm{~mm}$

Diameter of the screw $(\mathrm{ds})=50 \mathrm{~mm}$

Press diameter $(\mathrm{dp})=75 \mathrm{~mm}$

Press length $(\mathrm{Lp})=38 \mathrm{~mm}$

\section{Belt Drive:}

Power is transmitted from the prime mover to machine part by means of intermediate mechanism called Drives. Belt is used to transmit motion from one shaft to another with help of pulleys preferably if the center distance is long.

\section{FABrication Details}

\section{Hopper:}
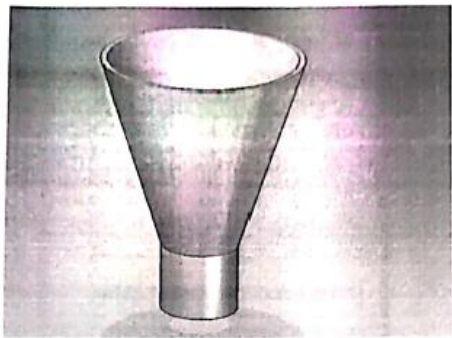

Fig 10: Hopper

Hopper having larger diameter $300 \mathrm{~mm}$, smaller diameter $100 \mathrm{~mm}$ and total height $400 \mathrm{~mm}$.

Material used-mild steel

\section{Spike drum:}

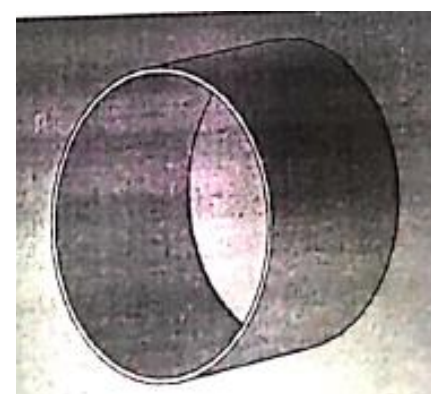

Fig 11: spike drum

Length of the cylinder $=400 \mathrm{~mm}$

Diameter $=300 \mathrm{~mm}$

Material used-mild steel

Hole of $5 \mathrm{~mm}$ is drilled for filtering coir powder.

Finishing and welding operation is carried out.

\section{Rotating drum:}

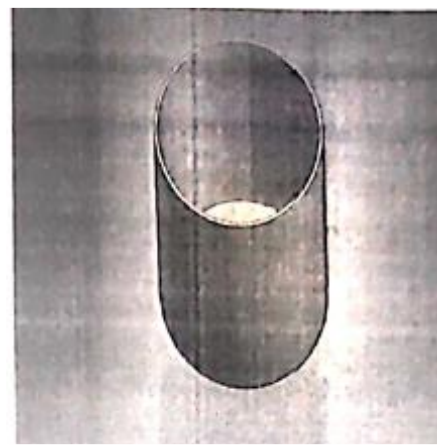

Fig 12: Rotating drum

Length $=250 \mathrm{~mm}$

Diameter $=150 \mathrm{~mm}$

Material-Mild steel

Fixed inside the spike drum with help of flange and shaft.

Finishing operations are carried out.

\section{Shaft:}

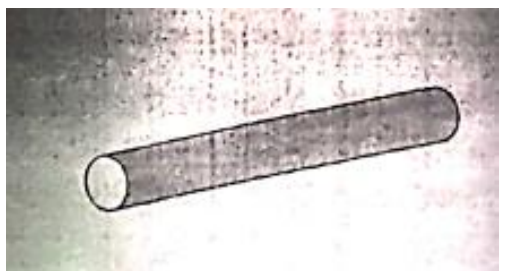

Fig 13: Shaft

Length $=480 \mathrm{~mm}$

Diameter $=45 \mathrm{~mm}$

Material $=$ MS

\section{Driver and driven pulley:}

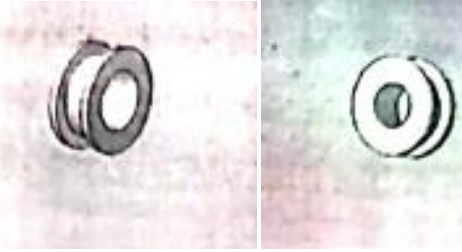

Fig 14: Driver and driven pulley

Inner diameter (driver)-25mm

Outer diameter (driver)-43 mm

Connected to motor through belt.

Inner diameter (driven)-20mm

Outer diameter (driven)-43 mm

Connected to shaft through belt.

\section{Pressing cylinder:}

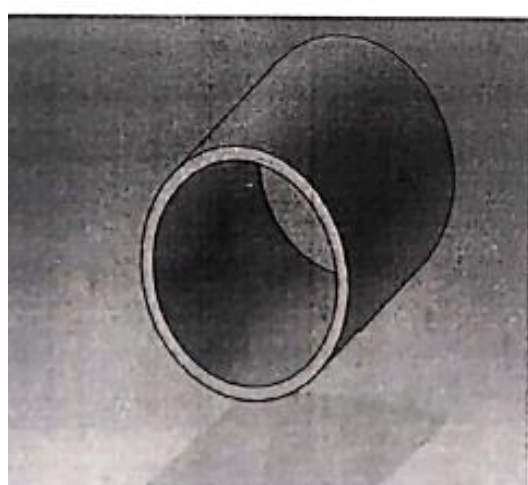

Fig 15: pressing cylinder 
Length $=145 \mathrm{~mm}$

Diameter $=98 \mathrm{~mm}$ (inner)

Diameter $=110 \mathrm{~mm}$ (outer)

\section{Screw Press:}

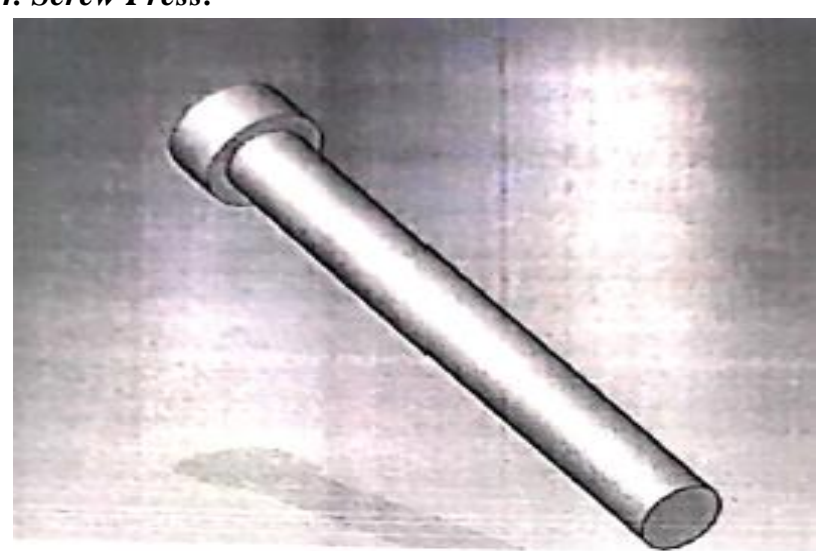

Fig 16: Screw Press

Length $=412 \mathrm{~mm}$

Diameter $=50 \mathrm{~mm}$

Press diameter $($ ram diameter $)=75 \mathrm{~mm}$

Press length $=38 \mathrm{~mm}$

Thread thickness $=5 \mathrm{~mm}$

Pitch $=8 \mathrm{~mm}$

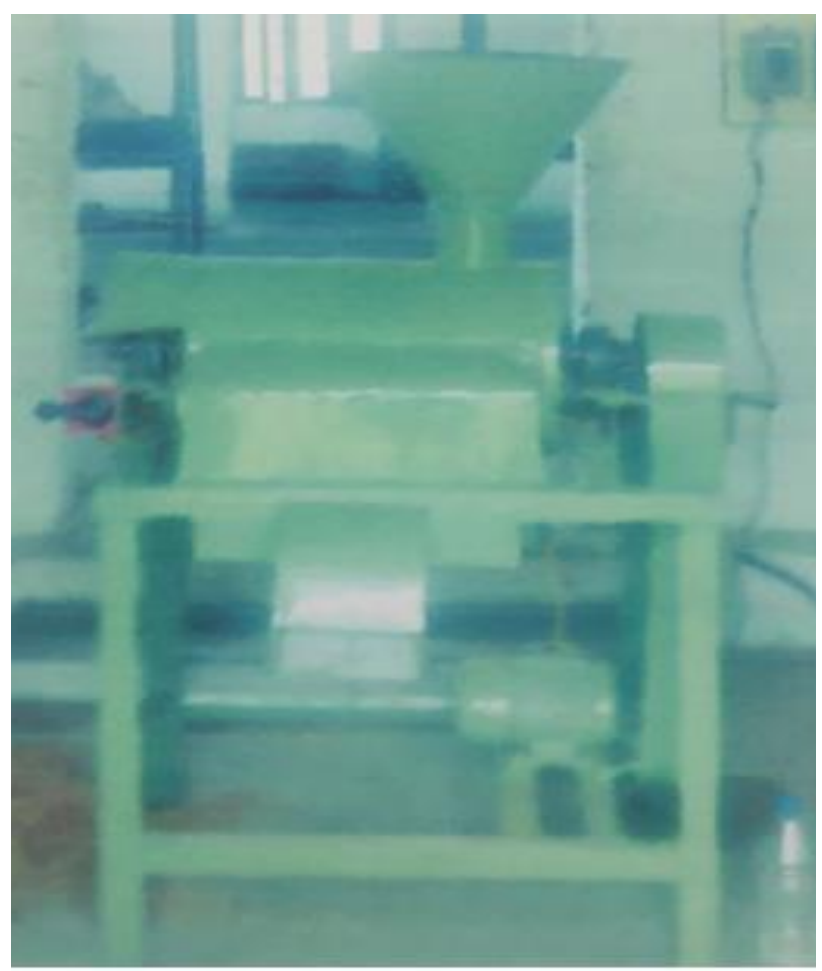

Fig 17: Fabricated assembly of coir pith briquetting machine

\section{TEST RESULTS}

The Below images are the examples for potting medium where coir pith products are effectively utilized as a manure to grow the plants.

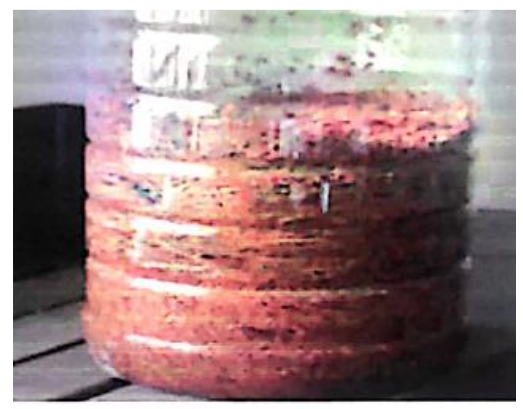

Fig 18: Before compression

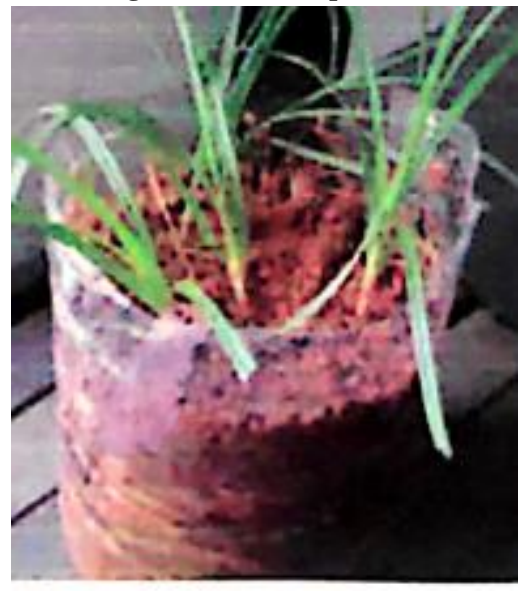

Fig 19: After compression

Table 4: Dry Density calculations (Before compression)
\begin{tabular}{|c|l|c|}
\hline SL No. & \multicolumn{1}{|c|}{ Properties } & Quantity \\
\hline 1 & Dry weight & $0.140 \mathrm{~kg}$ \\
\hline 2 & Dry mass & $0.01427 \mathrm{~kg}$ \\
\hline 3 & $\begin{array}{l}\text { Height of pith in dry } \\
\text { codition }\end{array}$ & $0.1550 \mathrm{~m}$ \\
\hline 4 & Dry density & $7.502 \mathrm{~kg} / \mathrm{m}^{3}$ \\
\hline
\end{tabular}

Table 5: Dry Density calculations (After compression)

\begin{tabular}{|c|l|c|}
\hline \multicolumn{1}{|l|}{ SL No. } & \multicolumn{1}{|c|}{ Properties } & Quantity \\
\hline 1 & Dry weight & $0.140 \mathrm{~kg}$ \\
\hline 2 & Dry mass & $0.01427 \mathrm{~kg}$ \\
\hline 3 & $\begin{array}{l}\text { Height of pith in dry } \\
\text { codition }\end{array}$ & $0.07 \mathrm{~m}$ \\
\hline 4 & Dry density & $16.61 \mathrm{~kg} / \mathrm{m}^{3} \mathrm{~kg} / \mathrm{m}^{3}$ \\
\hline
\end{tabular}

Table 6: Bulk Density calculations

\begin{tabular}{|l|l|l|}
\hline SI No. & Properties & Quantities \\
\hline 1 & Wet weight & $0.980 \mathrm{~kg}$ \\
\hline 2 & Wet mass & $0.0998 \mathrm{~kg}$ \\
\hline 3 & Height after absorption water & $0.145 \mathrm{~m}$ \\
\hline 4 & Amount of water & $100 \mathrm{ml}$ \\
\hline 5 & Bulk density & $56.08 \mathrm{~kg} / \mathrm{nr}^{<-}$ \\
\hline
\end{tabular}




\section{CONCLUSIONS}

1. Coir pith is a useful product to produce better yield in the field of agriculture and in home nurseries.

2. This is a new technique proposed for maintaining the growth of plants in the potting medium

3. The fertile growth of plants during the summer season, dry lands and also at the time of deficiency of minerals in the soil can be avoided using coir pith product.

4. The best way to bring the existing coir industry to a higher level is by the development of new coir products with higher added value.

\section{ACKNOWLEDGMENT}

I'm extremely grateful to our guide Prof. Daivagna for providing this opportunity and motivation.

\section{REFERENCES}

[1] Groover, P.D and S K Mishra. Food and Agriculture organization of the united nation,1996.publication printed by FAO Regional Wood energy Development Programme in Thailand, Asia.

[2] Guile Newman, Branch smith publications, core facts about the coir,pp-1 to 3,2009.

[3] Saunders, WB and KD wager, Environmental Management, Co., Philadelphia, USA,1998.

[4] Peter fellow and A. Quauich, production methods, equipment and quality assurance practices,2004

[5] Jafferjee Brothers and Hayley Zylylon, composite application using coirfibres in srilanka,project no. CFC/FIGHFI/18FT,2003

[6] Physical, chemical and biological properties of coir dust by M Prasad, ISHS Acta Horticulture.1996.

[7] Anita Das Ravindranath. Bio-processing of Coir-A Natural Fibre for Diversified End Use. 2015

[8] Narendra Reddy. Agricultural Applications of Coir. 2019.

[9] Development of Briquette from Coir Dust and Rice Husk Blend: An Alternative Energy Source, Md Abdul Momin, june 2014.

[10] A Novel Method for Accelerated Composting of Coir Pith by Prasanta K. Ghosh, U. S. Sarma, Anita Das, Ravindranath S, Radhakrishnan and Prasenjeet Ghosh,feb 17, 2007. 